Maruy ama et al.

\title{
Dynamics of microcystin-degrading bacteria in mucilage of Microcystis
}

Tomoko Maruyama, ${ }^{1,2}$ Kenji Kato, ${ }^{1 *}$ Atsushi Yokoyama, ${ }^{2}$ Toshiyuki Tanaka, ${ }^{2}$ Akira Hiraishi, ${ }^{3}$ Ho-dong Park ${ }^{2}$

${ }^{1}$ Department of Biology and Geosciences, Faculty of Science, Shizuoka University, Shizuoka 422-8529, Japan

${ }^{2}$ Department of Environmental Sciences, Faculty of Science, Shinshu University, Matsumoto 390-8621, Japan

${ }^{3}$ Department of Ecological Engineering, Toyohashi University of Technology, Toyohashi 441-8580, Japan

${ }^{*}$ Corresponding author: Kenji Kato, Department of Biology and Geosciences, Faculty of Science, Shizuoka University, 836 Oya, Shizuoka 422-8529, Japan

Tel: $+81-54-238-4950$

Fax: +81-54-238-4950

E-mail: skkato@ipc.shizuoka.ac.jp

Date submitted:

Running head: Microcystin-degrading bacteria in mucilage of Microcystis 


\section{Abstract}

To reveal the process of degradation of hepatotoxic microcystin produced in Microcystis cells during the Microcystis bloom period, we used fluorescence in situ hybridization (FISH) to analyze the population dynamics of microcystin-degrading bacteria in Microcystis mucilage. We designed and applied an oligonucleotide probe targeted to the 16S rRNA sequence of strain Y2 of a microcystin-degrading bacterium (MCD-bacterium), which was isolated from Lake Suwa, Japan. In both the 1998 and 1999 tests, FISH clearly showed that MCD-bacteria existed in the mucilage and that, when a high concentration of cell-bound microcystin was detected, MCD-bacteria exceeded $10 \%$ of the sum of bacteria hybridized with group-specific probes. The concentration of MCD-bacteria was highest in summer 1998, when a toxic species, $M$. viridis, was dominant. There was a high correlation between the number of MCD-bacteria in the mucilage and the concentration of cell-bound microcystin in the lake. Our results suggest that MCD-bacteria responded to changes in the concentration of microcystin and degraded the microcystin when it was released from Microcystis cells. We also analyzed changes in the bacterial community structure associated with the Microcystis colonies by using domain- and group-specific oligonucleotide probes. Changes in the concentrations of the Cytophaga Flavobacterium group and $\delta$-Proteobacteria, which can degrade macromolecules derived from Microcystis cells, were synchronized with changes in the concentration of Microcystis. The results not only suggest the significant role of MCD-bacteria in detoxification, but also demonstrate a possible sequence of degradation from Microcystis cells to microcystin maintained in the cell, which is then carried out by bacterial consortia in the mucilage. 


\section{Introduction}

Microcystin, a cyclic hepatotoxin, causes serious disease, as reported by Jochimsen et al. [20]. In 1996, 54 out of 130 patients at a dialysis center in Caruaru, Brazil, died from water for dialysis contaminated by microcystins, which are produced by some cyanobacteria of the genera Microcystis, Anabaena, Nostoc, and Oscillatoria. Of these, Microcystis, which blooms in eutrophic tropical and temperate lakes and ponds, is the most common cyanobacterium [10].

Microcystin is produced and maintained within healthy cyanobacterial cells. Approximately $10 \%$ to $20 \%$ of microcystin is lost from healthy cyanobacterial cells in culture [40, 41]. When Microcystis cells are decayed, the concentration of dissolved microcystin may increase [44]. However, dissolved microcystin concentrations remain very low in lake water, even during the decay of Microcystis [36]. Jones and Orr [21] used high-performance liquid chromatography (HPLC) and a protein phosphatase inhibition assay to determine the loss of microcystin released to lake water following algicidal treatment. Furthermore, Christoffersen et al. [14] showed in laboratory and field experiments that the degradation of microcystin by indigenous bacteria in lake water was accelerated by the existence of dissolved organic carbon (DOC), and that the addition of cell lysates of toxic Microcystis elevated bacterial abundance, production and diversity. However, the mechanism of in situ degradation of microcystin remains to be clarified. Jones et al. [22] isolated a single strain of microcystin-degrading bacterium (MCD-bacterium) identified as Sphingomonas sp. from drainage. Bourne et al. [8] used this strain in laboratory experiments focused on the process of enzymatic degradation of microcystin. However, they did not examine the degradation of microcystin by MCD-bacteria in natural water. In 1996, we independently isolated a strain of MCD-bacterium, Y2, which belongs to a new genus related to Sphingomonas, from eutrophic Lake Suwa in central Honshu, Japan [37]. In this study, we examined the process of degradation of microcystin by bacteria in the natural environment, focusing on the population dynamics of MCD-bacteria.

Degradation of microcystin produced in Microcystis occurs during the 2-fold decomposition process of Microcystis: (a) the cell decays by autolysis, grazing by protozoa, zooplankton and fish [13], or viral [27] or bacterial activity [15, 46], and (b) the cellular products are then degraded by bacterial consortia. Daft et al. [15] showed that a myxobacterium isolated from fresh water was able to lyse Microcystis. Yamamoto et al. [46] 
indicated that some bacteria of the genera Alcaligenes and Pseudomonas and the CytophagaFlavobacterium group also lysed Microcystis. Because these findings concerning cell decomposition of Microcystis were obtained by culture-dependent techniques, our knowledge is limited to the function of culturable bacteria. However, numerous non-culturable bacteria exist in the natural environment, exceeding $99 \%$ of the total bacterial count in various systems [11]. To complement this gap, the fluorescence in situ hybridization method (FISH, [2, 16]) was recently developed to identify individual cells, independent of culturability, at levels ranging from species to domain by using oligonucleotide probes specific to the $16 \mathrm{~S}$ or $23 \mathrm{~S}$ rRNA sequence. Modified FISH methods [12, $19,25,26,34]$ have also been developed to visualize the metabolic function of a specific bacterial group.

The aim of this study is to elucidate the process of the degradation of microcystin by MCD-bacteria under the possible coexistence with various other bacteria with varying functions during the bloom of Microcystis in Lake Suwa. Based on the FISH method, we designed an oligonucleotide probe specific to the 16S rRNA sequence of strain Y2, and applied several probes specific to phylogenetic groups to examine a structural changes in the associated bacterial community with Microcystis colonies during the periods of a Microcystis bloom and its decline

\section{Materials and methods}

\section{Sampling of heterotrophic bacteria associated with Microcystis colony}

Lake Suwa, located in Nagano Prefecture in Japan, is a eutrophic, temperate, shallow lake. The lake has a surface area of $13.3 \mathrm{~km}^{2}$, a maximum depth of $6.4 \mathrm{~m}$, and an average depth of $5 \mathrm{~m}$.

Samples of heterotrophic bacteria associated with Microcystis colonies were collected from the surface water of the center of the lake during Microcystis blooms on 26 August, 9 September, and 7 October 1998, and on 11 August, 25 August, 8 September, and 6 October 1999. As the biomass of Microcystis was significantly lower in 1999, we slightly changed the collection procedure slightly. In 1999, water samples were prescreened with a nylon net with a mesh size of $40 \mu \mathrm{m}$ and were kept in a glass bottle for a few hours. The floating Microcystis colonies and associated bacteria were then collected using a pipette. The isolated Microcystis colonies were filtered through a 3-um-pore-size Nuclepore filter, and washed 3 to 5 times with phosphate-buffered saline (pH 7.2, Dulbecco's 
PBS(-), Nissui, Japan) to eliminate any free-living bacteria. The washed colonies were sonicated 3 times (BRANSONIC B1200, $45 \mathrm{kHz}, 30 \mathrm{~W}, 3 \mathrm{~s} \mathrm{~mL}^{-1}$ ) to disrupt them and disperse the heterotrophic bacterial cells and Microcystis cells.

\section{Fixation of heterotrophic bacteria for total count and fluorescence in situ hybridization}

Heterotrophic bacterial samples for total bacterial count and FISH were fixed in paraformaldehyde solution (pH 7.4, final concentration 3\%) for up to $24 \mathrm{~h}$ at $4 \mathrm{C}$. To avoid destruction of the Microcystis colonies in 1998 or the Microcystis cells and bacterial cells in 1999, fixed samples for FISH were filtered gently on a $0.22-\mu \mathrm{m}$ Nuclepore filter (25 mm diameter) [23]. Cells on the filter were rinsed 3 times with PBS and dehydrated in $1 \mathrm{~mL}$ of $50 \%$, $80 \%$, and $99 \%$ ethanol for 3 min each, and the filter was then air-dried. Filters were stored at $-20 \mathrm{C}$ until hybridization.

\section{Total count of associated bacteria}

Fixed samples were stained with 4',6'-diamidino-2-phenylindole (DAPI, final concentration $0.01 \mu \mathrm{g} / \mathrm{mL}$ [39]) and filtered gently on a $0.22-\mu \mathrm{m}$ Nuclepore filter ( $25 \mathrm{~mm}$ diameter). A total of more than 1000 bacterial cells were enumerated by epifluorescence microscopy (universal epifluorescence microscopic system BX50-FLA, Olympus, Japan).

\section{Whole-cell in situ hybridization}

The 16S rRNA targeted oligonucleotide probes used in this study are shown in Table 1. They comprised a domain-specific probe for Bacteria (EUB338), phylogenetic-group-specific probes for $\alpha-, \beta-, \gamma-$, and 8-Proteobacteria (ALF1b, BET42a, GAM42a, DEL) and the Cytophaga Flavobacterium group (CF319a), and an MCD-probe designed specifically for microcystin-degrading bacteria ("strain Y2" in this study). These probes were labeled with rhodamine obtained from Takara Biotechnology (DALIAN), Japan.

Hybridization stringency was adjusted by varying the concentration of formamide in the hybridization buffer and $\mathrm{NaCl}$ in the washing solution. Hybridizations were performed at $46 \mathrm{C}$ for $90 \mathrm{~min}$ on filters placed on slides 
coated with gelatin, with hybridization buffer containing $0.9 \mathrm{M} \mathrm{NaCl}, 20 \mathrm{mM}$ Tris $\bullet \mathrm{HCl}$ (pH 7.4), $0.01 \%$ SDS, formamide (20\% for EUB338, ALFlb, CF319a, and MCD, 35\% for BET42a, GAM42a and DEL), and $5 \mathrm{ng} \mu \mathrm{L}$ ${ }^{-1}$ of the respective labeled probe. Each filter was washed at $48 \mathrm{C}$ for $15 \mathrm{~min}$ in pre-warmed washing buffer containing $\mathrm{NaCl}$ (0.225 M for EUB338, ALFlb, and MCD, 0.080 M for BET42a, GAM42a and DEL), $20 \mathrm{mM}$ Tris $\bullet \mathrm{HCl}(\mathrm{pH} 7.4), 5 \mathrm{mM}$ EDTA, and 0.01\% SDS, rinsed with distilled water, and air-dried. The preparations, which were counterstained with $0.1 \mu \mathrm{g} \mathrm{mL}^{-1}$ DAPI [45] on glass slides for $5 \mathrm{~min}$, were observed under a universal epifluorescence microscopic system, BX50-FLA with a 3CCD camera (C5810, Hamamatsu Photonics, Japan) with an image analysis system (SP500F, Olympus). More than 500 DAPI-stained bacterial cells were counted to determine the proportion of the probe-specific-labeled cells among the total of the associated bacteria.

The accuracy of the MCD-probe had previously been examined by using sequences of the 16S rRNA gene obtained from a GenBank: the MCD-probe was found to contain 1 mismatch for the 2 other known sequences of the 16S rRNA gene in the database; both sequences had been isolated from marine oligotrophic bacteria (AB021704, AB022713). These bacteria, which were obtained courtesy of Dr. I. Yoshinaga of Kyoto University, were not succeeded in hybridization of the designed MCD-probe with various condition of hybridization adjusted by concentration of formamide and temperature. There exist some arguments about the binding strength between the sequences of the designed probe and the target position of $16 \mathrm{~S}$ rRNA. According to the reports of Fuchs et al. [17], the 16S rRNA position of the MCD-probe was not easily hybridized. However, we confirmed that $\mathrm{Y} 2$ strain was successfully visualized by using MCD-probe.

Determination of concentrations of Microcystis cells, chlorophyll a, and total cell-bound and extracellular microcystin in the lake

To determine the concentrations of Microcystis, chlorophyll $a$, and cell-bound and extracellular microcystin, surface water samples were collected from the center of the lake once two weeks between April and December in 1998 and 1999. Samples for cell counting of Microcystis were fixed in formaldehyde solution (final concentration, $1.5 \% \mathrm{w} / \mathrm{v})$. The concentration of Microcystis cells was estimated by using a Fuchs-Rosenthal hemocytometer (Kayagaki works, Japan) under a microscope (BH-2, Olympus). 
To measure the chlorophyll $a$ concentration, water samples were filtered through a glass fiber filter $(\mathrm{GF} / \mathrm{C}$, Whatman, UK), which was then soaked in $10 \mathrm{~mL}$ of methanol for $24 \mathrm{~h}$ at $4^{\circ} \mathrm{C}$. After that, the residue was centrifuged at $3000 \mathrm{rpm}$ for $15 \mathrm{~min}$. Measurement of the chlorophyll $a$ concentration from the supernatant was quantified spectrophotometrically by the method of Maker et al. [31].

Measurements of microcystin concentration and the clean-up of microcystin in preparation for high-performance liquid chromatography (HPLC) were carried out according to Park et al. [36]. For measurement of cell-bound microcystin, Microcystis cells were concentrated on a GF/C filter. The filter was then homogenized and extracted with $5 \%$ aqueous acetic acid, and, after centrifugation at $4000 \mathrm{rpm}$ for $15 \mathrm{~min}$, the supernatant was poured into an ODS cartridge (Bakerbond spe Octadecyl $\left[\mathrm{C}_{18}\right] 3 \mathrm{~mL}$, USA). Microcystin extracted from the cartridge with $0.1 \%$ trifluoroacetic acid (TFA) - methanol was applied to the HPLC system (LC-9A S-I, Shimadzu, Japan), which was equipped with an ODS column (Cosmosil 5C18-AR 4.6 $\times 150 \mathrm{~mm}$, Nacalai, Japan). The conditions of HPLC for analysis of microcystin were as follows: absorbance at $238 \mathrm{~nm}$; methanol: $0.05 \mathrm{M}$ phosphate buffer (58:42; $\mathrm{pH} 3.0)$ in the mobile phase; and a 1-mL-min ${ }^{-1}$ flow rate.

Extracellular microcystin was measured by 2 methods using a GF/C filtrate. In 1998, the GF/C filtrate sample was poured into an ODS cartridge (5 g, Chromatorex ODS, 100-200 mesh, Fuji Silysia Chemical, Kasugai, Japan). The cartridge was then rinsed with water and then with $20 \%$ methanol. Extracellular microcystin was eluted from the cartridge with $90 \%$ methanol and evaporated to dryness. After a silica gel cartridge ( $2 \mathrm{~g}$, SepPak) had been preconditioned with methanol, the residue was dissolved in methanol and applied to the cartridge. After the cartridge was rinsed with methanol, extracellular microcystin was eluted with $70 \%$ methanol. The eluate was evaporated to dryness, and the residue was re-dissolved in methanol. The methanol solution was then analyzed by HPLC under the same conditions as above.

In 1999, extracellular microcystin was analyzed by enzyme-linked immunosorbent assay (ELISA), which determined the total concentration of microcystins without discriminating microcystin derivatives. Nagata et al. [33] showed very similar estimates from ELISA and a liquid chromatographic method for the analysis of microcystin, although the sensitivity of the ELISA method was higher. Thus, we used the ELISA method after Nagata et al. [32, 33]. 


\section{Results}

Concentrations of Microcystis cells, chlorophyll a, and cell-bound and extracellular-microcystin during Microcystis blooms

Changes in the concentrations of Microcystis, chlorophyll $a$, and cell-bound microcystin in water are given in Figure 1. In 1998 Microcystis appeared in the middle of June and bloomed, the dominant species being $M$. ichthyoblabe in July, and M. viridis from August to October. Relative proportion of Microcystis biomass formed more than $99 \%$ in total phytoplankton biomass during the blooming period of Microcystis. The concentration of Microcystis cells had 2 peaks: $2.4 \times 10^{9}$ cells L $\mathrm{L}^{-1}$ on 29 July, and over $7 \times 10^{8}$ cells $\mathrm{L}^{-1}$ on 9 and 25 September, after which dates it decreased (Fig. 1A-1). The chlorophyll $a$ concentration also showed 2 large peaks: $662 \mu \mathrm{g} \mathrm{L}$ on 29 July and over $600 \mu \mathrm{g} \mathrm{L} \mathrm{L}^{-1}$ on 9 and 25 September. By 7 October it had decreased markedly to $180 \mu \mathrm{g} \mathrm{L}$ (Fig. 1A-2). The cell-bound microcystin concentration increased exponentially in September up to $100 \mu \mathrm{g} \mathrm{L}^{-1}$, then decreased to $50 \mu \mathrm{g} \mathrm{L}$ or less in October (Fig. 1A-2). Although the changes in Microcystis cell concentration were paralleled by those of chlorophyll $a$ and cell-bound microcystin, nonparametric Spearman statistical analysis showed significance only between the concentration of Microcystis cells and chlorophyll $a(r=0.95, P<0.01, \mathrm{n}=$ 12). The concentration of cell-bound microcystin fluctuated in parallel with that of chlorophyll $a(r=0.81, P<$ $0.01, \mathrm{n}=13$ ). The extracellular microcystin concentration in the water was less than $0.5 \mu g \mathrm{~L}^{-1}$ throughout the 1998 study period (Table 2) - similar to the findings of Park et al. [36]. The concentration of extracellular microcystin was the highest on 29 July; by 3 December it had decreased to below the detection limit. Although its fluctuation was similar in pattern to that of the Microcystis cell concentration, no significant relationship between the two was detected by nonparametric Spearman statistical analysis.

In contrast to 1998, a minor bloom of Microcystis was observed in September 1999, showing that relative proportion of Microcystis biomass formed more than $99 \%$ in total phytoplankton biomass. It consisted of $M$. ichthyoblabe, M. aeruginosa, M. novacekii, and M. wesenbergii. However, none of those strains dominated strikingly. The abundance of Microcystis was 1 order of magnitude lower than that in 1998, ranging from $4.3 \times$ $10^{6}$ to $6.8 \times 10^{7}$ cells L ${ }^{-1}$ (Fig. 1B-1). The concentrations of chlorophyll $a$ and cell-bound microcystin from 11 August to 6 October in 1999 ranged from 16 to $48 \mu g \mathrm{~L}^{-1}$ and from 0.54 to $4.49 \mu \mathrm{g} \mathrm{L} \mathrm{L}^{-1}$, respectively (Fig. 1B-2). 
Cell-bound microcystin was not analyzed between April and July, as the biomass of Microcystis was insignificant. The total concentration of extracellular microcystin in the water was less than $0.2 \mu \mathrm{g} \mathrm{L^{-1 }}$ throughout the observation period (Table 2). Although the changes in the concentrations of cell-bound microcystin and extracellular microcystin appeared to parallel changes in the Microcystis cell concentration, nonparametric Spearman statistical analysis failed to show any significant relationships.

\section{Population dynamics of bacteria associated with Microcystis}

The density of bacteria associated with the Microcystis colonies ranged from $7.2 \times 10^{6}$ to $8.5 \times 10^{7}$ cells $\mathrm{mL}^{-1}$ of lake water in 1998 and from $1.1 \times 10^{4}$ to $3.2 \times 10^{5}$ cells $\mathrm{mL}^{-1}$ in 1999 (Table 3). The number of bacterial cells associated with each Microcystis cell increased from 25 on 26 August to 118 on 9 September 1998, but did not change markedly in 1999, ranging from 2.6 to 4.7 cells. The highest concentration of associated bacteria in the lake water was found on 9 September 1998 and on 8 September 1999, reaching $8.5 \times 10^{7}$ and $3.2 \times 10^{5}$ cells mL ${ }^{-1}$, respectively. Whereas associated bacteria constituted $95 \%$ of the total bacteria in the water on 9 September 1998 , associated bacteria in the 1999 study period constituted only $0.2 \%$ to $3.3 \%$ of the total bacteria. The difference in the concentration of associated bacteria between 1998 and 1999 was ascribed to the difference in the species composition of Microcystis.

\section{Changes in community structure of associated bacteria}

The community structure of bacteria associated with Microcystis was expressed on the basis of the number of each bacterial species, as determined by rRNA-targeted oligonucleotide probes, per $10^{2}$ cells of Microcystis (Fig. 2), because an average colony of Microcystis in Lake Suwa consisted of at least $10^{2}$ cells, although it fluctuated ranging from 127 to 529 cells. In 1998, the concentration of domain Bacteria visualized with the probe EUB338 ranged from $1.4 \times 10^{3}$ to $7.9 \times 10^{3}$ cells per $10^{2}$ Microcystis cells, and the Bacteria were composed of between $56 \%$ and $69 \%$ DAPI-stained particles (data not shown). $\alpha$-Proteobacteria were the second most common after B-Proteobacteria on 9 September and 7 October, increasing from $2.6 \times 10^{2}$ (26 August) to $2.0 \times 10^{3}$ (7 October) cells per $10^{2}$ Microcystis cells ( $18 \%$ to $26 \%$ of the sum of the bacteria hybridized by the oligonucleotide probes 
specific to $\alpha-, \beta-, \gamma-$, and $\delta$--Proteobacteria and the CytophagaFlavobacterium group) (Fig. 2A-1). $\beta$-Proteobacteria were dominant during the blooming of Microcystis, ranging from $5.1 \times 10^{2}$ to $2.7 \times 10^{3}$ cells per $10^{2}$ Microcystis cells $(28 \%$ to $36 \%)$. $\gamma$-Proteobacteria increased from $3.8 \times 10^{2}\left(26\right.$ August) to $1.3 \times 10^{3}(7$ October) cells per $10^{2}$ Microcystis cells ( $17 \%$ to $27 \%$ ). $\delta$-Proteobacteria made up the lowest percentage of the sum of bacteria hybridized with group-specific probes on 26 August, 9 September, and 7 October (5.3\% to $13 \%)$. However, this group increased from only 75 (26 August) to $9.9 \times 10^{2}$ (9 September) cells per $10^{2}$ Microcystis cells. This increase was about 2- to 4-fold higher than that of other groups in the period from August to September. The concentration of the Cytophaga/Flavobacterium group increased from $1.9 \times 10^{2}$ (26 August) to $1.5 \times 10^{3}$ (7 October) cells per $10^{2}$ Microcystis cells ( $13 \%$ to $\left.20 \%\right)$.

In 1999, the concentrations of domain Bacteria visualized with EUB338 ranged from $3.1 \times 10^{2}$ to $3.9 \times 10^{2}$ cells per $10^{2}$ Microcystis cells, and the Bacteria were composed of between $78 \%$ and $94 \%$ DAPI-stained particles (data not shown). These numbers were higher than those in 1998, although the density of associated bacteria in 1999 was about 100 times less than in 1998. $\alpha$-Proteobacteria existed at concentrations of between $1.2 \times 10^{2}$ cells and $1.4 \times 10^{2}$ cells per $10^{2}$ Microcystis cells throughout the study period (Fig. 2B-1), and predominated in all samples, accounting for at least $30 \%$ of the sum of bacteria hybridized with group-specific probes. $\beta$-Proteobacteria also remained nearly constant at $1.0 \times 10^{2}$ cells per $10^{2}$ Microcystis cells during the study period, constituting from $26 \%$ to $31 \%$ of the sum of bacteria hybridized with group-specific probes - a similar percentage to that in 1998. $\gamma$-Proteobacteria ranged from 49 to 57 cells per $10^{2}$ Microcystis cells ( $13 \%$ to $\left.18 \%\right)$. The densities of these 3 phylogenetic groups were similar to each other during the 1999 observations. $\delta$-Proteobacteria and the Cytophaga/Flovobacterium group showed similar fluctuations with regard to relative abundance and cell density: both parameters for both groups had increased by 8 September and decreased by 6 October. The number of $\delta$ Proteobacteria ranged from 11 to 50 cells per $10^{2}$ Microcystis cells, reaching a peak on 8 September. This group made up only $3.5 \%$ to $13 \%$ of the sum of bacteria hybridized with group-specific probes. The Cytophaga/Flavobacterium group ranged from 13 to 69 cells per $10^{2}$ Microcystis cells ( $4.0 \%$ to $18 \%$ ), reaching a maximum on 8 September.

MCD-bacteria had increased remarkably in both relative abundance and density of associated bacteria per $10^{2}$ 
Microcystis cells by 9 September 1998 (Fig. 2A-2). MCD-bacteria increased remarkably from 93 cells to $1.3 \times$ $10^{3}$ cells per $10^{2}$ Microcystis cells between 26 August and 9 September, and by 7 October had decreased to $7.8 \times$ $10^{2}$ cells per $10^{2}$ Microcystis cells, thus accounting for $6.6 \%$ to $17 \%$ of the total bacteria hybridized with group-specific probes. Their relative abundance among $\alpha$-Proteobacteria was also high, ranging from $36 \%$ to $76 \%$ (data not shown). In 1999, MCD-bacteria ranged from 20 to 41 cells per $10^{2}$ Microcystis cells and showed a tendency to increase in numbers in September, accounting for $6.1 \%$ to $11 \%$ of the sum of bacteria hybridized with group-specific probes (Fig. 2B-2). The relative abundance of MCD-bacteria among $\alpha$-Proteobacteria was not as high as in 1998, ranging from $17 \%$ to $34 \%$. The highest proportions of MCD-bacteria, in relation to both the sum of bacteria hybridized with group-specific probes and $\alpha$-Proteobacteria, were observed on 8 September. These results from 1998 and 1999 indicated that the number of MCD-bacteria associated with $10^{2}$ Microcystis cells increased in September and then decreased in October, closely paralleling changes in the microcystin concentration in both the water $(r=1, P<0.01, \mathrm{n}=6)$ and Microcystis cells $(r=0.89, P<0.05, \mathrm{n}=6)$.

\section{Discussion}

Strains of several species of the genus Microcystis produce 60 variants of hepatotoxic microcystin [38]. $M$. viridis is 1 such toxic species in Lake Suwa $[35,36]$. The highest concentration of cell-bound microcystin was observed when M. viridis was dominant in September 1998.

Microcystis is surrounded by mucilage, which consists mainly of polysaccharide $[3,5]$ composed of glucose, mannose, fucose, xylose, galactose, and rhamnose. The thickness and solubility of the mucilage vary among Microcystis species [4, 24]: the mucilage of $M$. viridis is harder to dissolve in water than those of the other species [4]. During blooms, numerous bacteria are known to exist in the mucilage [9]. Furthermore, the abundance and community structure of the embedded bacteria might differ according to the Microcystis species.

When microcystin is released from a cell of Microcystis, it is trapped in the mucilage because of the mucilage's high viscosity. To reveal the process of degradation of microcystin, we therefore focused on the function of the bacteria embedded in the mucilage and tried to describe the population dynamics of the MCD-bacteria there. Our results revealed that the number of MCD-bacteria in the mucilage increased in September of both years and 
correlated with the concentration of cell-bound microcystin, and the highest concentration of MCD-bacteria existed in 1998 when M. viridis was dominant. It is remarkable in natural systems that 1 gene specific clone of MCD-bacteria detected by FISH made up 1/10 of the whole bacterial community in September 1998 and 1999. These results suggest that MCD-bacteria responded to changes in the concentration of microcystin, and that MCD-bacteria were active in the mucilage of Microcystis when produced microcystin was present there. Jones et al. [22] reported that microcystin-degrading isolates require a lag time in the degradation of microcystin when they have not been exposed to microcystin a priori under experimental conditions. However, we assumed that MCD-bacteria in the mucilage were on 'stand-by' until the degradation of microcystin occurred: they could be directly exposed to any microcystin released from cells in the Microcystis colony. This suggests that MCD-bacteria could thus initiate the degradation of microcystin in the mucilage within 2 weeks so far we examined. These findings can explain why a bacterial species becomes predominant in a given system if it exerts a very specific function to degrade a specific compound, such as microcystin.

During the bloom of Microcystis, the concentrations of the CytophagaFlavobacterium group and $\delta$-Proteobacteria were apparently synchronized with that of the Microcystis cells, with $r=0.89(P<0.05, \mathrm{n}=6)$ and $r=0.94(P<0.05, \mathrm{n}=6)$, respectively. To our knowledge, members of the Cytophaga Flavobacterium group are able to degrade not only macromolecular compounds [12, 43], but also Microcystis cells [46]. Van Hannenn [43] suggested that Cytophagales, the related 16S rRNA sequence of which appeared in denaturing gradient gel electrophoresis after the lysis of cyanobacteria, could contribute to degradation of dissolved organic matter (DOM) released from this lysis. Recently, Cottrell and Kirchman [12] suggested from fluorescence in situ hybridization (MICRO-FISH) studies that the mode of bacterial utilization of DOM differs among phylogenetic groups: the CytophagaFlavobacterium group tends to prefer high-molecular-weight DOM such as proteins and chitin. Yamamoto et al. [46] showed by a culture-dependent method that some Microcystis were lysed specifically by some strains of this group isolated from the surface waters of Lake Suwa. These findings suggest that the CytophagaFlavobacterium group contributes to the lysis of Microcystis and degrades DOM derived from intracellular products of Microcystis in the mucilage. Grilli Caiola et al. [18] reported that Bdellovibrio-like bacteria, constituents of the $\delta$-Proteobacteria, infect Microcystis cells and degrade peptidoglycan and the cell wall, although 
Bdellovibrio is known to be a bacterial predator [6]. This suggests that $\delta$-Proteobacteria might contribute to the lysis of Microcystis.

$\alpha$-Proteobacteria and $\beta$-Proteobacteria tended to dominate in the mucilage of Microcystis during the bloom of Microcystis. Of the $\alpha$-Proteobacteria, Caulobacter can attach to cyanobacteria and take up exudates of photosynthetic products [42]. Alcaligenes and Pseudomonas, which are $\beta$-Proteobacteria, are known to lyse Microcystis cells by attaching to them $[28,46]$.

We studied the process of degradation of microcystin in the light of changes in bacterial community structure in a natural environment, focusing particularly on strain Y2 of MCD-bacteria, which belongs to an undescribed genus [37]. We found that MCD-bacteria existed in a restricted space of the mucilage of Microcystis, and that the change in concentration of these bacteria was synchronized with the increase in the concentration of cell-bound microcystin. This suggests that MCD-bacteria in the mucilage responded to changes in the concentration of cell-bound microcystin; the microcystin was exuded from the cell of toxic Microcystis and degraded by the bacteria. The Cytophaga Flavobacterium group and $\delta$-Proteobacteria also changed their population densities in the mucilage, suggesting that they contributed to the degradation of Microcystis cells. Mucilage is revealed not only as a compound that binds Microcystis cells together, but also as a habitat for bacteria that exert their specific function to utilize and thus degrade Microcystis cellular materials. 


\section{Acknowledgments}

This work was supported in part by a grant from the Ministry of Health, Labor and Welfare, Japan (Research in Environmental Health H11-Seikatsu-015, and Nagano Prefecture Techno-Highland Development Organization) in 1998 .

\section{References}

1. Amann RI, Binder BJ, Olson RJ, Chrisholm SW, Devereux R, Stahl DA. (1990) Combination of 16S rRNA-targeted oligonucleotide probes with flow cytometry for analyzing mixed microbial populations. Appl Environ Microbiol 56:1919-1925

2. Amann RI, Ledwig W, Schleifer K-H. (1995) Phylogenetic identification and in situ detection of individual microbial cells without cultivation. Microbiol Rev 59:143-169

3. Amemiya Y, Nakamura O. (1986) Some properties of the sheath material. Rep Fac Engineer, Yamanashi Univ $37: 70-75$

4. Amemiya Y, Kato K, Nakayama O. (1988) Extracellular products of Microcystis species: Formation of slime layer and DOC pool in surrounding waters. Verh Int Ver Limnol 23:1886-1892

5. Amemiya Y, Kato K, Okino T, Nakayama O. (1990) Changes in the chemical composition of carbohydrates and proteins in surface water during a bloom of Microcystis in Lake Suwa. Ecol Res 5:153-162

6. Brock TD (1970) Prokaryoic diversity: bacteria. In: Michael TM, John MM, Jack P. (eds), The Biology of Microorganisms, 8th ed: Prentice Hall, New Jersey, p 684

7. Brosius J, Dull TL, Sleeter DD, Noller HF. (1981) Gene organization and primary structure of a ribosomal RNA operon from Escherichia coli. J Molec Biol 148:107-127

8. Bourne DG, Jones GJ, Blakeley RL, Jones A, Negri AP, Riddles P. (1996) Enzymatic pathway for the bacterial degradation of the cyanobacterial cyclic peptide toxin microcystin LR. Appl Environ Microbiol 62:4086-4094

9. Brunberg A-K. (1999) Contribution of bacteria in the mucilage of Microcystis spp. (Cyanobacteria) to benthic and pelagic bacterial production in a hypereutrophic lake. FEMS Microbiol Ecol 29:13-22 
10. Carmichael WW. (1992). A status report on planktonic cyanobacteria (blue-green algae) and their toxins. EPA/600/R- 92/079, Environmental Monitoring system laboratory, Office of Research and Development, US Environmental Protection Agency, Cincinnati Ohio.

11. Colwell RR, Grims DJ. (2000) Semantics and strategies. p. 3. In R. R. Colwell, and D. J. Grimes (eds), Nonculturable Microorganisms in the Environment. ASM Press, Washington DC, USA

12. Cottrell MT, Kirchman DL. (2000) Natural assemblages of marine proteobacteria and members of the Cytophaga-Flavobacter cluster consuming low- and high-molecular weight dissolved organic matter. Appl Environ Microbiol 66:1692-1697

13. Christoffersen K. (1996) Ecological implications of cyanobacterial toxins in aquatic food webs. Phycologia 35: $42-50$

14. Christoffersen K, Lyck S, Winding A. (2002) Microbial activity and bacterial community structure during degradation of microcystins. Aquat Microb Ecol 27:125-136

15. Daft MJ, McCord SB, Stewart WDP. (1975) Ecological studies on algal-lysing bacteria in fresh waters. Freshwat Biol 5:577-596

16. Delong, EF, Wickham GS, Pace N. (1989) Phylogenetic stains: ribosomal RNA-based probes for the identification of single cells. Science 243:1360-1363

17. Fuchs BM, Wallner G, Beisker W, Schwippl I, Ludwig W, Amann R. 1998 Flow cytometric analysis of the in situ accessibility of Escherichia coli 16S rRNA for fluorescently labeled oligonucleotide probes. Appl Environ Microbiol 62:1998-2005

18. Grilli Caiola M, Pellegrini S, Geora FM, Ribaldone A. (1991) Bdellovibrio-like bacteria in Microcytsis aeruginosa. Arch Hydrobiol Suppl Algol Stud 64:369

19. Hodson RE, Dustman WA, Garg RP, Moran MA. (1995) In situ PCR for visualization of microscale distribution of specific genes and gene products in prokaryotic communities. Appl Environ Microbiol $61: 4074-4082$

20. Jochimsen EM, Carmichael WW, An J, Cardo DM, Cookson ST, Holmes CEM, Antunes BC, de Melo Filho DA, Lyra TM, Barreto VST, Azevedo AMFO, Jarvis WR. (1998) Liver failure and death after 
exposure to microcystins at a hemodialysis center in Brazil. N Eng J Med 338:873-878

21. Jones GJ, Orr PT (1994) Release and degradation of microcystin following algicide treatment of a Microcystis aeruginosa bloom in a recreational lake, as determined by HPLC and protein phosphatase inhibition assay. Wat Res 28:871-876

22. Jones GJ, Bourne DG, Blakeley RL, Doelle H. (1994) Degradation of the cyanobacterial hepatotoxin microcystin by aquatic bacteria. Natural Toxins 2:228-235

23. Kato K, Sakamoto M. (1983) The function of free-living bacterial fraction in the organic matter metabolism of mesotrophic lake. Arch Hydrobiol 97:287-302

24. Komárek J. (1991) A review of water-bloom forming Microcystis species, with regard to populations from Japan. Arch Hydrobiol Suppl Algol Stud 64:115-127

25. Lange M, Tolker-Nielsen T, Molin S, Ahring BK. (2000) In situ reverse transcription-PCR for monitoring gene expression in individual Methanosarcina mazei S-6 cells. Appl Environ Microbiol 66:1796-1800

26. Lee N, Nielsen PH, Andereasen KH, Luretschko S, Nielsen J, Schleifer K-H, Wagner M. (1999) Combination of fluorescent in situ hybridization and microautoradiography—new tool for structure-function analysis in microbial ecology. Appl Environ Microbiol 65:1289-1297

27. Manage PM, Kawabata Z, Nakano S-I. (1999) Seasonal changes in densities of cyanophage infectious to Microcystis aeruginosa in a hypereutrophic pond. Hydrobiologia 411:221-216

28. Manage PM, Kawabata Z, Nakano S-I. (2000) Algicidal effect of the bacterium Alcaligenes denitrificans on Microcystis spp. Aquat Microb Ecol 22:111-117

29. Manz W, Amann R, Ludwig W, Wagner M, Schleifer K-H. (1992) Phylogenetic oligooxynucleotide probes for the major subclasses of proteobacteria; problems and solutions. Syst Appl Microbiol 15:593-600

30. Manz W, Amann R, Ludwig W, Vancanneyt M, Schleifer K-H. (1996) Application of a suite of 16SrRNA-specific oligonucleotide probes designed to investigate bacteria of the phylum cytophaga-flavobacter-bacterioides in natural environment. Microbiology 142:1097-1106

31. Marker AFH, Nusch EA, Rai H, Riemann B. (1980). The measurement of photosynthetic pigments in fresh waters and standardization of methods: conclusions and recommendations. Arch Hydrobiol Beih 14:91-106 
32. Nagata S, Soutome H, Tsutsumi T, Hasegawa A, Sekijima M, Sugamata, M, Harada K-I, Suganuma M, Ueno Y. (1995) Novel monoclonal antibodies against microcystin and their protective activity for hepatotoxicity. Natural Toxins 3:78-86

33. Nagata S, Tsutsumi T, Hasegawa A., Yoshida F, Ueno Y. (1997) Enzyme immunoassay for direct determination of microcystins in environmental water. J AOAC Int 80:408-417

34. Ouverney CC, Fuhrman JA. (1999) Combined microautography-16S rRNA probe technique for determination of radioisotope uptake by specific microbial cell types in situ. Appl Environ Microbiol $65: 1746-1752$

35. Park H-D, Watanabe MF, Harada K-I, Suzuki M, Hayashi H, Okino T. (1993) Seasonal variations of Microcystis species and toxic heptapeptide microcystins in Lake Suwa. Environ Toxicol Water Qual $8: 425-435$

36. Park H-D, Iwami C, Watanabe MF, Harada K-I, Okino T, and Hayashi H (1998) Temporal variabilities of the concentrations of intra- and extracellular microcystin and toxic Microcystis species in a hypertrophic lake, Lake Suwa, Japan (1991-1994). Environ Toxicol Water Qual 13: 61-72

37. Park H-D, Sasaki Y, Maruyama T, Yanagisawa E, Hiraishi A, Kato K. (2001) Degradation of the cyanobacterial hepatotoxin microcystin by a new bacterium isolated from a hypertrophic lake. Environ Toxicol 16:337-343

38. Park H-D, Namikoshi M, Brittain SM, Carmichael WW, Murphy T. (2001) [D-Leu ${ }^{1}$ ] microcystin -LR, a new microcystin isolated from waterbloom in a Canadian prairie lake. Toxicon 39:855-862.

39. Poter KG, Feig YS. (1980) The use of DAPI for identifying and counting aquatic microflora. Limnol Oceanogr 25:943-948

40. Rapala J, Sivonen K, Lyra C, Niemelä, SI. (1997) Variation of microcystins, cyanobacterial hepatotoxins, in Anabaena spp. as a function of growth stimuli. Appl Environ Microbiol 63:2206-2212

41. Sivonen K. (1990) Effect of light, temperature, nitrate orthophosphate, and bacteria on growth of and hepatotoxin production by Oscillatoria agardhii strains. Appl Environ Microbiol $56: 2658-2666$

42. Stanier RY. (1976) Gram-negative bacteria: aerobic chemoheterotrophs. In: Stanier RY, Adelberg EA, 
Ingraham JL (eds), The Microbial World, 4th ed: Prentice-Hall, New Jersey, pp 598-602

43. Van Hannen EJ, Zwart G, van Agterveld MP, Gons HJ, Ebert J, Laanbroek HJ. (1999) Changes in bacterial and eukaryotic community structure after mass lysis of filamentous cyanobacteria associated with viruses. Appl Environ Microbiol 65:795-801

44. Watanabe MF, Tsuji K, Watanabe Y, Harada K-I, Suzuki M. (1992) Release of hepatotoxin (microcystin) during the decomposition process of Microcystis aemuginosa. Natural Toxins 1:48-53

45. Weiss P, Schweitzer B, Amman R, Simon M. (1996) Identification in situ and dynamics of bacteria on limnetic organic aggregates (Lake Snow). Appl Environ Microbiol 62:1998-2005

46. Yamamoto Y, Nizuma S, Kuroda N, Sakamoto M. (1993) Occurrence of heterotrophic bacteria causing lysis of cyanobacteria in a eutrophic lake. Jpn J Phycol 41:215-220 
Maruyama et al.

Table 1. Probe sequences and target sites

\begin{tabular}{|c|c|c|c|c|}
\hline Probe name & Target arganism & Sequence & $\begin{array}{l}\text { Target site }^{\mathrm{a}} \\
\text { rRNA Position }\end{array}$ & Reference \\
\hline EUB338 : & domain Bacteria & 5'-GCTGCCTCCCGTAGGAG T-3', & $16 \mathrm{~S}, 338-355$ & 1 \\
\hline ALF $1 b$ : & a-Proteobacteria & 5'-CGTTCG(C/T)TCTGAGCCAG-3' & $16 \mathrm{~S}, 19-35$ & 29 \\
\hline BET42a : & b-Proteobacteria & 5'-GCCTCCCCACTTCGTTT-3' & $23 \mathrm{~S}, 1027-1043$ & 29 \\
\hline GAM42a & g-Proteobacteria & 5'-GCCTCCCCACATCGTTT-3' & $23 \mathrm{~S}, 1027-1043$ & 29 \\
\hline DEL : & d-Proteobacteria & 5'-CGGCGTCGCTGCGTCAGG-3' & $16 \mathrm{~S}, 385-402$ & 1 \\
\hline CF319a: & Cytophaga/Flavobacteriungroup & 5'-TGGTCCGTGTCTCAGTAC-3' & $16 \mathrm{~S}, 319-336$ & 30 \\
\hline $\mathrm{MCD}$ : & MCD-bacteria & 5'-CGCCACCAAAGCC TAAAAGG-3' & $16 \mathrm{~S}, 839-858$ & This study \\
\hline
\end{tabular}

${ }^{a}$ Escherichia coli numbering. [7]

Table 2. Concentration of extracellular microcystin in Lake Suwa, 1998 and 1999

\begin{tabular}{|c|c|c|}
\hline Year & Date & $\begin{array}{l}\text { extracellular microcystin } \\
\text { concentration }\left(\mu \mathrm{g} \mathrm{L}^{-1}\right)\end{array}$ \\
\hline \multirow[t]{6}{*}{$1998^{\mathrm{a}}$} & Jun. 17 & 0.05 \\
\hline & Jul.29 & 0.47 \\
\hline & Aug. 26 & 0.24 \\
\hline & Sept. 25 & 0.17 \\
\hline & Oct. 21 & 0.09 \\
\hline & Dec. 3 & N.D. \\
\hline \multirow[t]{7}{*}{$1999^{b}$} & May.20 & 0.09 \\
\hline & Jul. 28 & 0.03 \\
\hline & Aug. 11 & 0.04 \\
\hline & Aug. 25 & 0.10 \\
\hline & Sept. 8 & 0.12 \\
\hline & Sept. 22 & 0.08 \\
\hline & Oct. 6 & 0.06 \\
\hline
\end{tabular}

"Microcystin determined with HPLC. Sum of microcystin-LR and -RR.

${ }^{b}$ Microcystin determined with ELISA.

${ }^{\mathrm{N}} \mathrm{N} . \mathrm{D}$., microcystin not detected. 
Table 3. Number of Microcystis cells, free-living bacteria and bacteria associated with colonies of Microcystis

\begin{tabular}{|c|c|c|c|c|c|c|c|c|c|c|}
\hline \multirow[b]{3}{*}{ 1998. Aug. 26} & \multirow{3}{*}{$\begin{array}{l}\text { Concentration of } \\
\text { Microcystis cells } \\
\text { (cells } \mathrm{mL}^{-1} \text { ) }\end{array}$} & \multicolumn{4}{|c|}{ Associated bacteria } & \multirow[t]{2}{*}{ ૧० ४ } & \multirow{2}{*}{\multicolumn{3}{|c|}{$\begin{array}{l}\text { Free-living bacteria } \\
\text { (cells } \mathrm{mL}^{-1} \text { ) }\end{array}$}} & \multirow{3}{*}{$\begin{array}{c}\begin{array}{c}\text { Ratio of associated } \\
\text { bacteria to total } \\
\text { bacteria }(\%)\end{array} \\
61\end{array}$} \\
\hline & & \multicolumn{3}{|c|}{$\left(\text { cells mL }{ }^{-1}\right)^{\mathrm{a}}$} & \multirow{2}{*}{$\begin{array}{c}\text { (cells Micr ocystis } \text { cell }^{-1} \text { ) } \\
25.1 \pm 36.8\end{array}$} & & & & & \\
\hline & & $7.2] 10^{6}$ & \pm & $1.1 \square 10^{7}$ & & $4 . \otimes$ & $10^{6}$ & \pm & $1.1 \square 10^{6}$ & \\
\hline Sept. 9 & $7.4 \square 10^{5}$ & $8.510^{7}$ & \pm & $1.8 \square 10^{8}$ & $116 \pm 248$ & 4.30 & $10^{6}$ & \pm & $1.1 \square 10^{6}$ & 95 \\
\hline Oct. 7 & $2.2 \square 10^{5}$ & $2.6 \square 10^{7}$ & \pm & $4.2 \square 10^{7}$ & $118 \pm 193$ & 3.90 & $10^{6}$ & \pm & $9.2 \square 10^{5}$ & 87 \\
\hline 1999. Aug. 11 & $4.3 \square 10^{3}$ & $1.1 \square 10^{4}$ & \pm & $3.0 \square 10^{3}$ & $2.6 \pm 0.7$ & $7.5 \square$ & $10^{6}$ & \pm & $1.5 \square 10^{6}$ & 0.2 \\
\hline Aug. 25 & $3.9 \square 10^{4}$ & $1 . \varpi 10^{5}$ & \pm & $7.7 \square 10^{4}$ & $4.0 \pm 2.0$ & $7.8 \square$ & $10^{6}$ & \pm & $2.010^{6}$ & 1.9 \\
\hline Sept. 8 & $6.8 \square 10^{4}$ & $3.2 \square 10^{5}$ & \pm & $1.0 \square 10^{5}$ & $4.7 \pm 1.5$ & $9.4 \square$ & $10^{6}$ & \pm & $1 . \Im 10^{6}$ & 3.3 \\
\hline Oct. 6 & $1.1 \square 10^{4}$ & $3.8 \square 10^{4}$ & \pm & $1.2 \square 10^{4}$ & $3.5 \pm 1.1$ & $5 . \pi$ & $10^{6}$ & \pm & $1.2 \square 10^{6}$ & 0.7 \\
\hline
\end{tabular}

$\mathrm{a}_{\square}$ Microcystis cells per mL of lake water $૨$ ૧ bacteria associated with Microcystis per Microcystis cell $\square$ 


\section{Legends}

\section{Figure 1}

Seasonal changes in the concentrations of Microcystis cells, chlorophyll $a$, and cell-bound microcystin at the center of Lake Suwa in 1998 (A) and 1999(B). A-1 and B-1 show the concentrations of Microcystis cells (triangles). A-2 and B-2 show the concentrations of chlorophyll $a$ (open circles) and cell-bound microcystin (closed circles).

\section{Figure 2}

The composition of the bacterial assemblages in Microcystis colonies, as detected by rRNA-targeted oligonucleotide probes specific for $\alpha-, \beta-, \gamma$-, and $\delta$-Proteobacteria, the CytophagaFlavobacterium group, and microcystin-degrading bacteria. Samples were collected from the surface waters of Lake Suwa on 26 August, 9 September, and 7 October 1998 (A), and on 25 August, 8 September, and 6 October 1999 (B), when Microcystis was in bloom.

\section{Figure 3}

In situ hybridization of bacteria associated with colonies of Microcystis, viewed by epifluorescence microscopy. Bacteria in the colony of Microcystis stained by DAPI (A), and hybridized with a rhodamine-labeled probe specific to microcystin-degrading bacteria (B). Particles about $5 \mu \mathrm{m}$ in diameter are cells of Microcystis. 

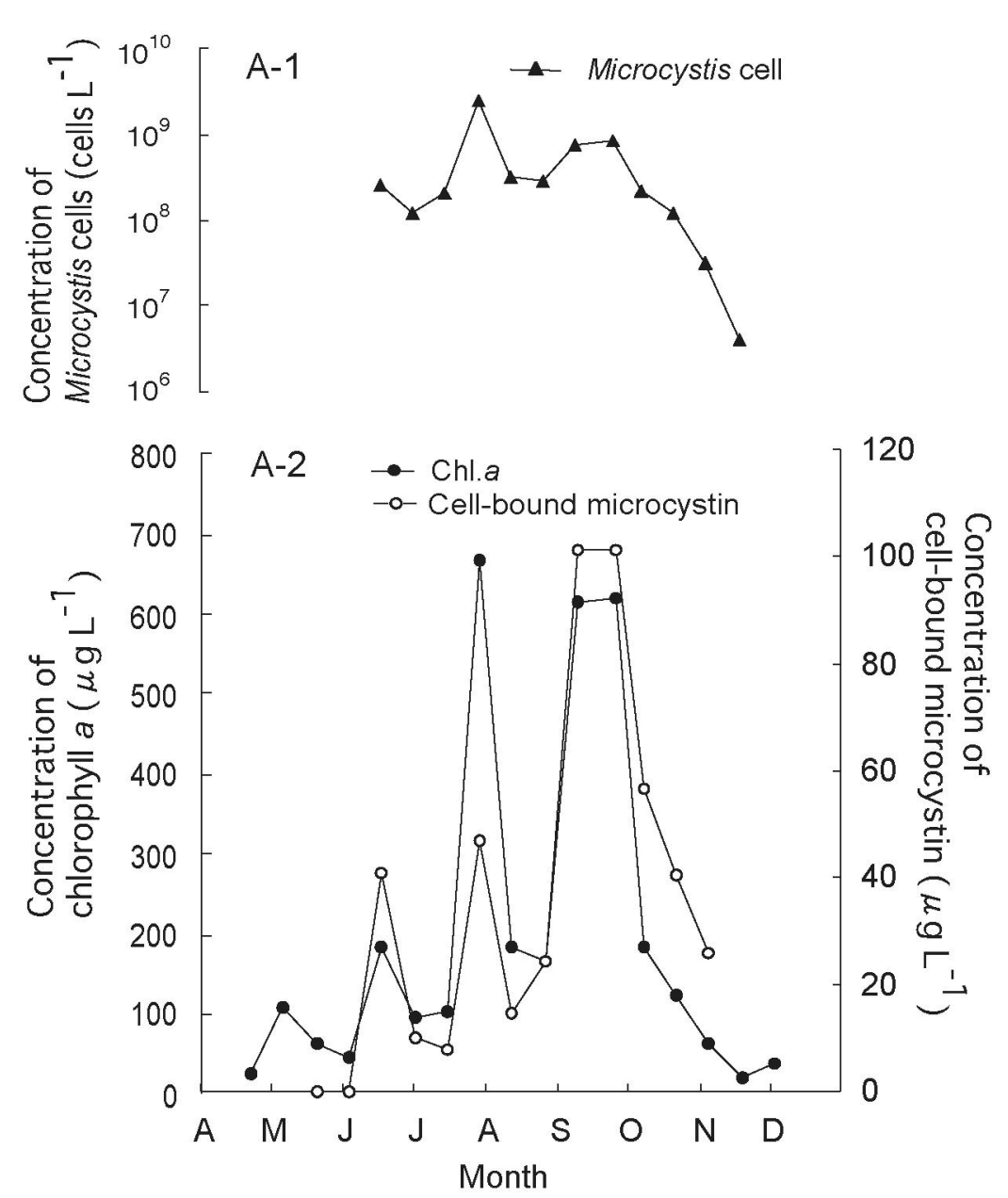

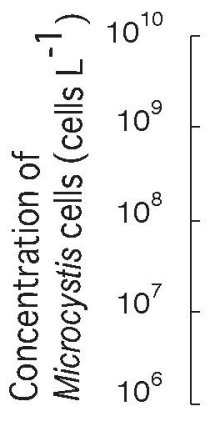

B-1

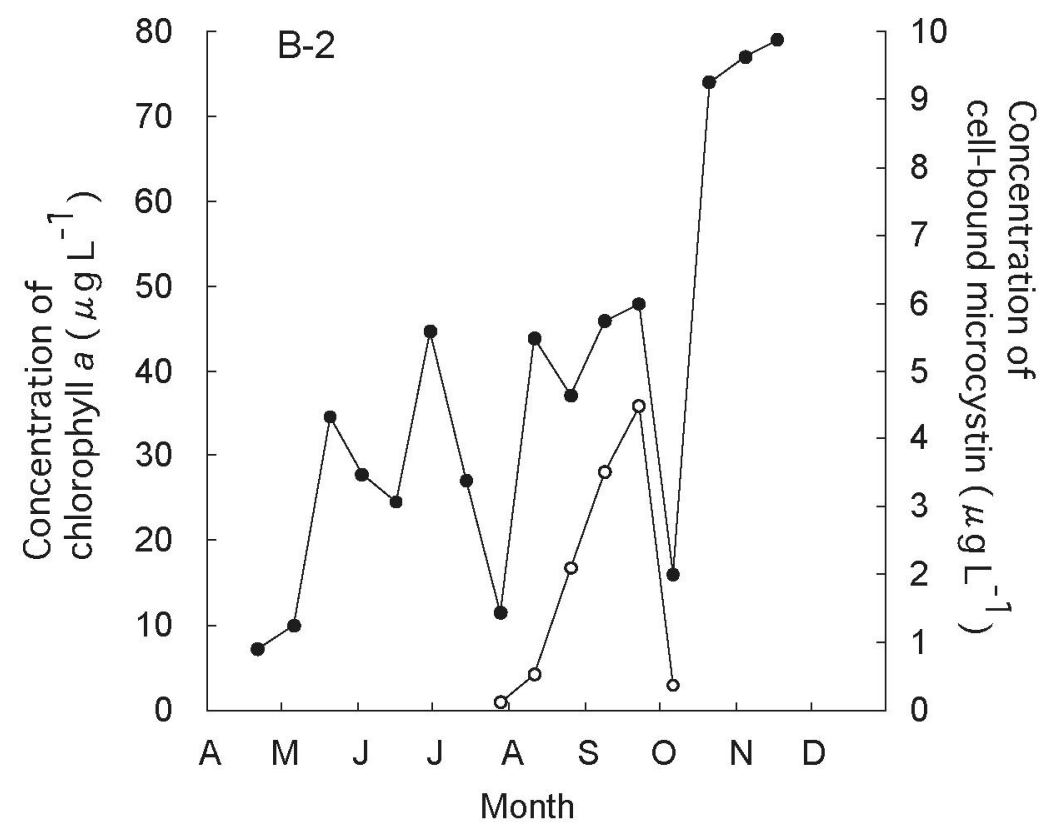

Fig. 1 
1998

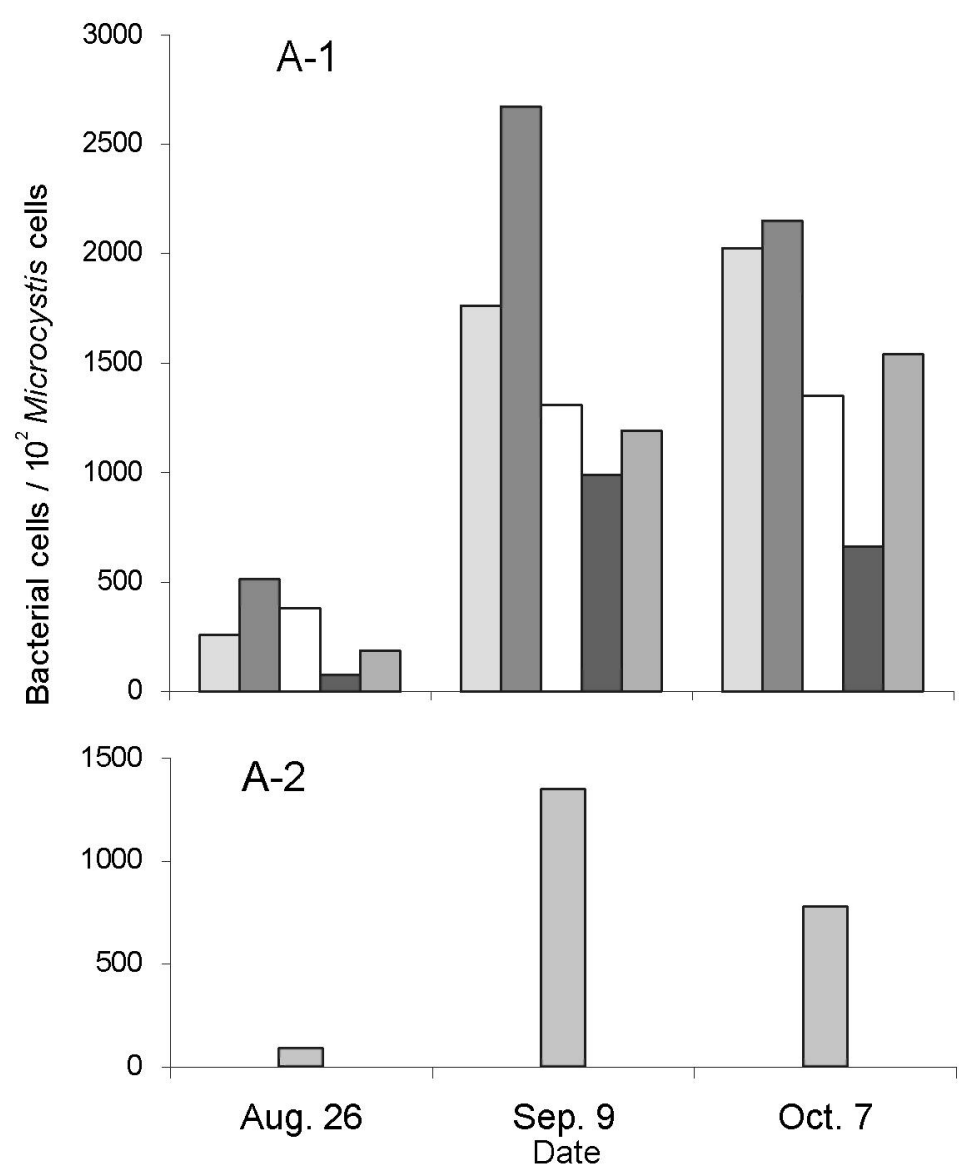

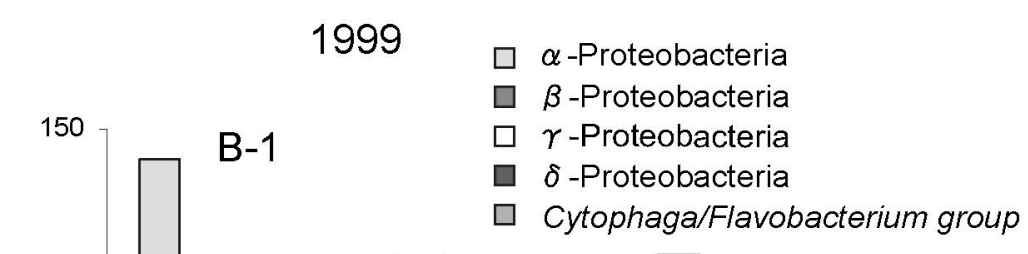

Fig. 2 

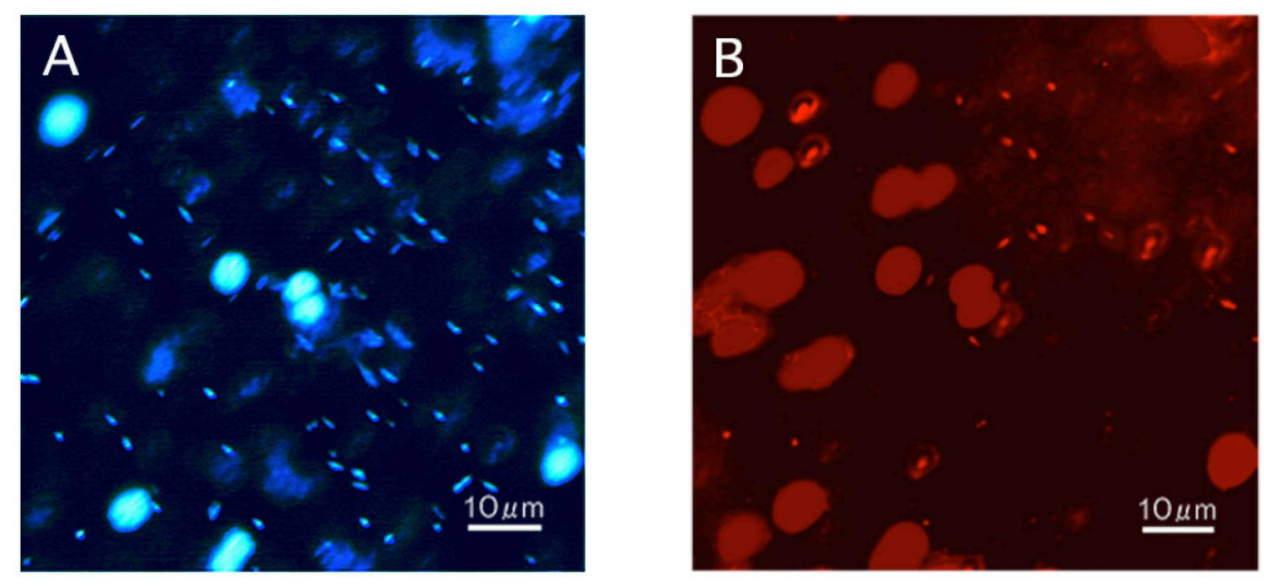

Fig. 3 